\title{
Abutment Screw Loosening in Single-Implant Restorations: A Systematic Review
}

\author{
Anna Theoharidou, DDS ${ }^{1} /$ Haralampos P. Petridis, DDS, $\mathrm{PhD}, \mathrm{MSc}^{2} /$ \\ Konstantinos Tzannas ${ }^{3} /$ Pavlos Garefis, DDS, $\mathrm{PhD}^{4}$
}

\begin{abstract}
Purpose: The purpose of this study was to systematically review clinical studies on the incidence of abutment screw loosening in single-implant restorations with different implant-abutment connection geometries. Materials and Methods: The literature search was conducted using several electronic databases. Specific terms were used for the database search, which spanned the years 1990 to 2006. The search was augmented by using the option of "related articles" as well as hand searching of references and relevant journals. Relevant studies were selected according to predetermined inclusion and exclusion criteria. Agreement between reviewers was determined by using Cohen's kappa coefficients. Three-year complication-free rates (survival proportions) were calculated with the aid of a survival function, assuming constant failure rates. Summary estimates per group for complication-free rate after 3 years (M-estimator) were calculated using Tukey's biweight estimator. Results: The initial database search yielded 1,526 relevant titles. After the subsequent filtering process, 27 studies were finally selected. Interexaminer agreement ranged from good to perfect. The external-connection group comprised 12 studies following 586 single-implant restorations for a mean follow-up time that ranged from 3 to 5 years. The estimated percent of complication-free single-implant restorations after 3 years was $97.3 \%$ (95\% Cl: 95.6-98.3). The internal connection group comprised 15 studies following 1,113 single-implant restorations for a mean follow-up time that ranged from 3 to 10 years. The estimated percentage of complication-free single-implant restorations after 3 years was $97.6 \%$ (95\% Cl: 96.5-98.3). Conclusion: The results show that abutment screw loosening is a rare event in singleimplant restorations regardless of the geometry of implant-abutment connection, provided that proper antirotational features and torque are employed. INT J ORAL MAXILLOFAC IMPLANTS 2008;23:681-690
\end{abstract}

Key words: implant complications, implant geometry, meta-analysis, screw loosening, single implants

$\mathrm{T}$ he stability of the connection between different implant parts is important for the overall success of

\footnotetext{
${ }^{1}$ Doctoral Candidate, Department of Fixed Prosthesis and Implant Prosthodontics, School of Dentistry, Aristotle University of Thessaloniki, Thessaloniki, Greece.

${ }^{2}$ Lecturer, Department of Fixed Prosthesis and Implant Prosthodontics, School of Dentistry, Aristotle University of Thessaloniki, Thessaloniki, Greece.

${ }^{3}$ Statistician, DCS Company, Thessaloniki, Greece.

${ }^{4}$ Professor and Chair, Department of Fixed Prosthesis and Implant Prosthodontics, School of Dentistry, Aristotle University of Thessaloniki, Thessaloniki, Greece.
}

Correspondence to: Dr Haralampos P. Petridis, Department of Fixed Prosthesis and Implant Prosthodontics, School of Dentistry, Aristotle University of Thessaloniki, 54124 Thessaloniki, Greece. Fax:+302310999575. E-mail: Lpetridi@dent.auth.gr

Presented as an oral presentation during the annual International Association for Dental Research-Continental European Division (IADR-CED) meeting, which took place in Thessaloniki, Greece, September 26-29, 2007. the reconstruction. This is especially true for singletooth restorations, where a strong interlock between the abutment and implant is necessary. Various mechanisms have been proposed to connect the dental implant abutment to the implant body. Different systems vary in connection geometry, materials, and overall screw mechanics. The implant-abutment connection stability is also influenced by factors such as component fit, machining accuracy, saliva contamination, and screw preload. ${ }^{1-8}$ Most in vitro studies, ${ }^{9-12}$ with the exception of one, ${ }^{13}$ have demonstrated that internal connections are more mechanically stable than external flat (hex-type) connections. Loosening of abutment screws, particularly with the "classic" external-hex implant systems, has been a well-known technical problem, occurring mainly during the first 2 years after delivery of the crown. ${ }^{14-17}$ The stability of the external implant-abutment connection was subsequently improved by altering the screw alloys and their surfaces and applying proper torque values to establish higher initial preloads. ${ }^{3,18-21}$ 
Industry surveys ${ }^{22,23}$ have shown that externalhex implants still dominate the European and US markets, although there is a continuous rise in internal-connection implants. The literature is lacking studies that compare the incidence of abutment screw loosening in implant systems of different connection geometries following the improvements in screw materials and preload.

The purpose of this study was to systematically review clinical studies with respect to the incidence of abutment screw loosening in single-implant restorations and to compare external- and internalconnection systems.

\section{MATERIALS AND METHODS}

\section{Search Strategy}

The literature search was conducted by 2 reviewers (AT, $\mathrm{HP}$ ), using different electronic databases (MedlinePubMed, The Cochrane Register of RCTs, the database of abstracts of Reviews of Effects-DARE) for clinical studies reporting on the incidence of abutment screw loosening of various implant systems with different implant-abutment connection geometries. The search terms that were used, alone or in conjunction, were "screw complications," "screw loosening," "implant abutment complications," "implant-abutment interface," "implant-abutment connection," "preload," "torque," "screw mechanics," and "screw type."The years searched were 1990 to September 2006. The option of "related articles" was also used. Review articles, as well as references from different studies, were also used to identify relevant articles. Hand searching for the time span 1995-September 2006 was conducted for the following journals: Journal of Prosthetic Dentistry, International Journal of Prosthodontics, International Journal of Oral \& Maxillofacial Implants, Implant Dentistry, and Clinical Oral Implants \& Related Research.

\section{Selection of Studies}

The review process consisted of 2 phases. During the first phase, the review was conducted by the 2 reviewers together. Any disagreement was resolved by discussion and, in case of doubt, the full text of the article was obtained. Initially titles were screened for relevance, and the full text of the relevant abstracts was obtained. Hand searching of the selected journals, as well as searching of the references of the selected studies, was also implemented at this point. The articles obtained were screened during the first step of the review process using the following exclusion and inclusion criteria:

\section{Exclusion criteria}

1. Laboratory studies

2. Case reports

3. Technical articles

4. Studies in a language other than English or without an English abstract

\section{Inclusion criteria}

1. Studies reporting on single-implant restorations (SIR)

2. Clinical studies with follow-up

3. Mechanical complications reported

The selected full texts were further screened independently by 2 reviewers in the second phase of the review using the following inclusion criteria: (1) Mean follow-up period of at least 3 years, (2) Single-tooth abutments with antirotational features and proper torque used in external-hex connections, (3) number of patients stated, (4) number of SIR stated, (5) implant system stated, and (6) study outcome stated as mechanical complications involving abutment screw loosening. Inter-reviewer agreement was determined using Cohen's kappa coefficients.

The final included studies that passed the second phase in the review process were classified according to the strength of evidence into 4 categories according to Jokstad et $\mathrm{al}^{24}$ : (1) A1, controlled clinical trial with patient randomization (RCT); (2) A2, controlled clinical trial with split-mouth randomization (split-mouth RCT); (3) B, prospective controlled trial without randomization (CCT); and (4) C, clinical studies with different designs than categories $A$ and $B$ (retrospective, case series, etc).

Data of the final studies was tabulated according to implant-abutment connection geometry, and the incidence of abutment screw loosening was calculated. In cases where the study included both single restorations and fixed partial dentures without specifying which restorations presented with abutment screw loosening, the worst case scenario was recorded (all failures attributed to single crowns). In studies where only the minimum follow-up time was mentioned, that interval was used to measure the total exposure time of the restorations. In cases of multiple publications following the same cohort of patients, the study with the longest follow-up was taken into account.

Three-year complication-free rates (survival proportions) were calculated with the aid of survival function $S, S(t)=\exp \left(-t^{*}\right.$ failure rate), where $t=3$ years, assuming constant failure rates. Number of failures per study was considered to follow a Poisson distribution for the calculated sum of implant years. Summary estimates per group of rates for complication-free implants after 3 years (M-estimator) were 


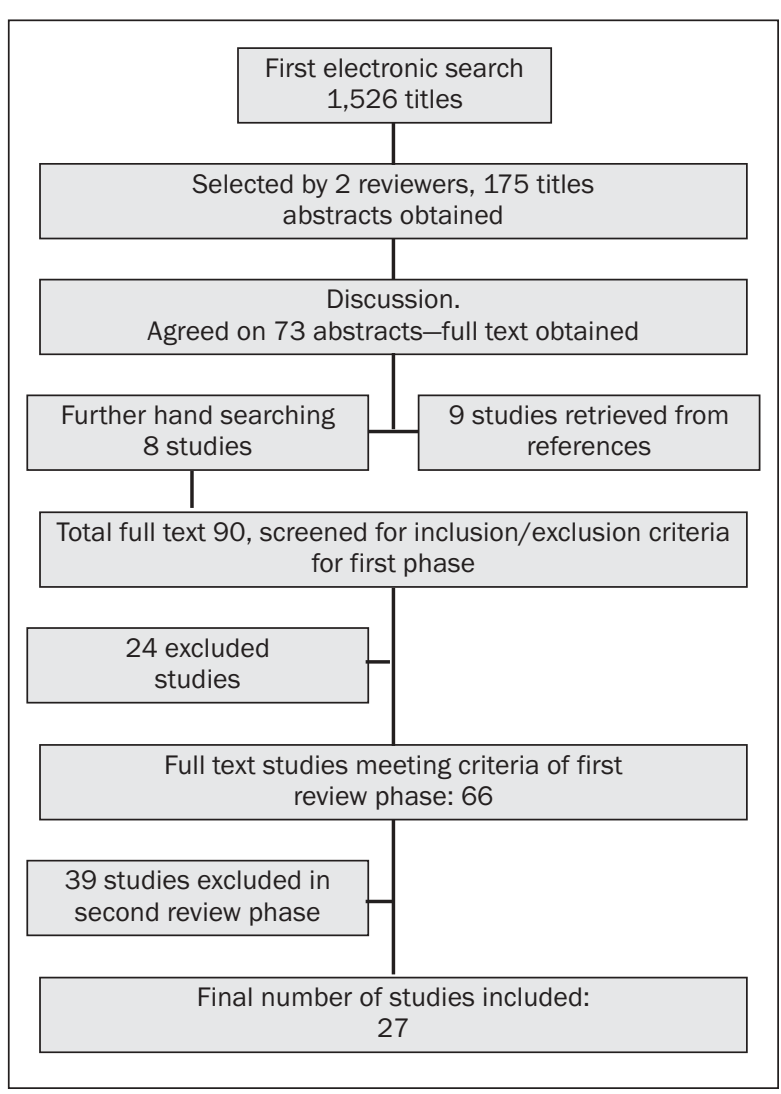

Fig 1 Search strategy and results.

calculated using Tukey's biweight estimator. The 95\% $\mathrm{Cl}$ for the complication-free rate per group was calculated from $95 \%$ confidence limits of the event rates. All analyses were performed using STATA, version 10 (Statacorp LP, College Station, TX) and $\mathrm{CMA}$, version 3 (Biostat, Englewood, $\mathrm{NJ}$ ).

The event rate of abutment screw loosening was compared between groups with different connection geometries. The possible effect of the type of study (prospective versus retrospective) on the outcome measured was also calculated.

\section{RESULTS}

The database search initially yielded 1,526 titles. Sixty-six studies passed the first review phase, and 27 studies ${ }^{25-51}$ were finally selected for analysis (Fig 1). The inter-reviewer agreement for the 6 inclusion criteria during the second review phase ranged from "good" to "very good" (kappa: 0.72-1.00; Table 1). The studies $^{52-89}$ that were rejected during the second review phase are shown in Table 2 .

\begin{tabular}{lccccc} 
Table 1 Inter-reviewer Agreement \\
Criterion & Kappa & $\begin{array}{c}\text { Standard } \\
\text { error }\end{array}$ & $\mathbf{9 5 \%} \mathbf{~ C l}$ \\
\hline Follow-up period & 0.750 & 0.058 & 0.635 & 0.865 \\
Proper method of fixation & 0.969 & 0.022 & 0.926 & 1.000 \\
No. of patients stated & 0.937 & 0.031 & 0.877 & 0.998 \\
No. of SIR stated & 1.000 & - & - & - \\
Implant system stated & 0.937 & 0.031 & 0.877 & 0.998 \\
Study outcome stated & 0.719 & 0.061 & 0.598 & 0.839 \\
\hline
\end{tabular}

Table 2 Excluded Studies During the Second Review Phase and Reason for Exclusion

\begin{tabular}{|c|c|}
\hline $\begin{array}{l}\text { Exclusion criteria/ } \\
\text { studies }\end{array}$ & Year \\
\hline \multicolumn{2}{|l|}{ Mean follow-up period $<3$ y } \\
\hline Levine et $\mathrm{al}^{52}$ & 1997 \\
\hline McMillan et al ${ }^{53}$ & 1998 \\
\hline Drago $^{19}$ & 2003 \\
\hline Dhanrajani and Al Rafee ${ }^{54}$ & 2005 \\
\hline Ericsson et al ${ }^{55}$ & 2000 \\
\hline Lindquist et al ${ }^{56}$ & 1996 \\
\hline Priest $^{57}$ & 1999 \\
\hline Levine et $a^{58}$ & 2002 \\
\hline Schropp et al ${ }^{59}$ & 2005 \\
\hline Andersson et al ${ }^{60}$ & 2003 \\
\hline Vermylen et al 61 & 2003 \\
\hline Karlsson et al 62 & 1997 \\
\hline Engquist et al ${ }^{16}$ & 1995 \\
\hline Jemt et $a^{63}$ & 1998 \\
\hline$W i e^{64}$ & 1995 \\
\hline \multicolumn{2}{|l|}{ No proper fixation } \\
\hline Lekholm et al 65 & 1994 \\
\hline Lekholm et al 66 & 1999 \\
\hline Jemt et $\mathrm{al}^{67}$ & 2000 \\
\hline \multicolumn{2}{|l|}{ Screw loosening not reported } \\
\hline Simon 68 & 2003 \\
\hline Kourtis et al ${ }^{69}$ & 2004 \\
\hline Haas et $\mathrm{al}^{70}$ & 1995 \\
\hline Polizzi et $\mathrm{al}^{71}$ & 1999 \\
\hline De Boever et al ${ }^{72}$ & 2006 \\
\hline Scurria et $\mathrm{al}^{73}$ & 1998 \\
\hline Bher et $\mathrm{al}^{74}$ & 1998 \\
\hline Wee and McGlumphy ${ }^{75}$ & 2003 \\
\hline Balshi and Wolfinger 76 & 1997 \\
\hline Henry et al ${ }^{17}$ & 1996 \\
\hline Fartash and Arvidson ${ }^{77}$ & 1997 \\
\hline Moberg et $\mathrm{al}^{78}$ & 1999 \\
\hline \multicolumn{2}{|l|}{ No. of patients not stated } \\
\hline Weig| ${ }^{79}$ & 2004 \\
\hline Döring et al ${ }^{80}$ & 2004 \\
\hline \multicolumn{2}{|l|}{ Implant system not stated } \\
\hline Cooper et al $\left.\right|^{81}$ & 2001 \\
\hline \multicolumn{2}{|c|}{ Mean follow-up period $<3$ y, screw loosening not reported } \\
\hline Norton 82 & 2004 \\
\hline \multicolumn{2}{|l|}{ Implant system not stated } \\
\hline Wennström et al ${ }^{83}$ & 2004 \\
\hline Schwartz-Arad et al ${ }^{84}$ & 1999 \\
\hline \multicolumn{2}{|c|}{ No proper fixation, no. of SIR not stated } \\
\hline Wyatt and Zarb ${ }^{85}$ & 1998 \\
\hline \multicolumn{2}{|c|}{ Mean follow-up period $<3$ y, no proper fixation } \\
\hline Ekfeldt et al ${ }^{15}$ & 1994 \\
\hline Carlson and Carlsson ${ }^{86}$ & 1994 \\
\hline
\end{tabular}


Table 3 Demographics of Included Studies with External Connection

\begin{tabular}{|c|c|c|c|c|c|c|c|c|c|}
\hline Study & Year & $\begin{array}{c}\text { Category } \\
\text { of evidence* }\end{array}$ & $\begin{array}{c}\text { Planned } \\
\text { no. of } \\
\text { patients }\end{array}$ & $\begin{array}{c}\text { Planned } \\
\text { no. of } \\
\text { patients } \\
\text { with SIR }\end{array}$ & $\begin{array}{c}\text { Actual } \\
\text { no. of } \\
\text { patients } \\
\text { with SIR }\end{array}$ & $\begin{array}{c}\text { Drop out } \\
\%\end{array}$ & $\begin{array}{c}\text { Age } \\
\text { range (y) }\end{array}$ & $\begin{array}{c}\text { Mean } \\
\text { age (y) }\end{array}$ & Setting \\
\hline Andersson et $\mathrm{al}^{28}$ & 1998 & $\mathrm{~B} 2(\mathrm{P})$ & 57 & 57 & 49 & 14 & $14-56$ & 32 & University \\
\hline Andersson et $\mathrm{al}^{34}$ & 2001 & A1(P RCT) & 15 & 15 & 15 & 0 & $17-49$ & 32 & University \\
\hline Balshi et $\mathrm{al}^{33}$ & 1996 & $\mathrm{C}(\mathrm{P})$ & 47 & 22 & 21 & 4.5 & NR & NR & Private \\
\hline Cho et $\mathrm{al}^{27}$ & 2004 & $C(P)$ & 106 & NR & NR & 0 & $20-74$ & NR & University \\
\hline Gibbard and Zarb32 & 2002 & $C(P)$ & 42 & 42 & 24 & 42.8 & $23-74$ & 42.7 & University \\
\hline Glauser et $\mathrm{al}^{36}$ & 2004 & $C(P)$ & 27 & 27 & 18 & 11.4 & $26-75$ & 44 & University \\
\hline Parein et $\mathrm{al}^{29}$ & 1997 & $C(R)$ & 152 & NR & NR & NR & $14-90$ & 55.7 & University \\
\hline Scheller et al ${ }^{31}$ & 1998 & $C(P)$ & 82 & 82 & 57 & 30.5 & $14-73$ & 35 & Private \\
\hline Scholander et al ${ }^{30}$ & 1999 & $\mathrm{C}(\mathrm{R})$ & 183 & 183 & NR & NR & $16-71$ & 29.8 & University \\
\hline Vigolo et $\mathrm{al}^{35}$ & 2004 & A1(P RCT) & 12 & 12 & 12 & 0 & NR & NR & Private \\
\hline
\end{tabular}

* Study design shown in parentheses. $N R=$ not reported, $\mathrm{R}=$ retrospective, $\mathrm{P}=$ prospective.

\section{Table 4 Demographics of Included Studies with Internal Connection}

\begin{tabular}{|c|c|c|c|c|c|c|c|c|c|}
\hline Study & Year & $\begin{array}{c}\text { Category } \\
\text { of evidence* }\end{array}$ & $\begin{array}{c}\text { Planned } \\
\text { no. of } \\
\text { patients }\end{array}$ & $\begin{array}{c}\text { Planned } \\
\text { no. of } \\
\text { patients } \\
\text { with SIR }\end{array}$ & $\begin{array}{c}\text { Actual } \\
\text { no. of } \\
\text { patients } \\
\text { with SIR }\end{array}$ & $\begin{array}{c}\text { Drop out } \\
\% \text { of } \\
\text { patients } \\
\text { with SIR }\end{array}$ & $\begin{array}{c}\text { Age } \\
\text { range (y) }\end{array}$ & $\begin{array}{c}\text { Mean } \\
\text { age (y) }\end{array}$ & Setting \\
\hline Behneke et al ${ }^{39}$ & 2000 & $C(P)$ & 55 & NR & NR & 0 & $17-81$ & 44.2 & University \\
\hline Brägger et al ${ }^{44}$ & 2004 & $C(P)$ & 89 & 48 & 48 & 0 & $28-88$ & 58.9 & University \\
\hline Duncan et al ${ }^{43}$ & 2003 & $C(P)$ & 51 & 19 & 19 & 0 & $21-76$ & 43.2 & University \\
\hline Mericske-Stern et al ${ }^{45}$ & 2001 & $C(P)$ & 75 & 75 & 71 & 5.3 & $19-82$ & 50.1 & University \\
\hline Nedir et al ${ }^{51}$ & 2006 & $C(R)$ & 236 & NR & NR & NR & $18-89$ & 57.5 & Private \\
\hline Levine et $\mathrm{al}^{37}$ & 1999 & $C(R)$ & 129 & 129 & 110 & 15 & $13-84$ & 52 & Private \\
\hline Wennström et al ${ }^{50}$ & 2005 & $\mathrm{C}(\mathrm{P})$ & 40 & 40 & 36 & 10 & $20-71$ & 40.9 & University \\
\hline Gotfredsen $^{49}$ & 2004 & $\mathrm{~B} 2(\mathrm{P})$ & 20 & 20 & 20 & 0 & $18-59$ & 33 & University \\
\hline Norton 48 & 2006 & $C(R)$ & 54 & 54 & 54 & 0 & $40-79$ & 57 & Private \\
\hline Norton 40 & 2001 & $C(P)$ & 23 & 23 & 13 & 43 & $23-77$ & 48.7 & Private \\
\hline Palmer et al ${ }^{38}$ & 2000 & $C(P)$ & 15 & 15 & 14 & 6.7 & $16-48$ & 33 & University \\
\hline Krennmair et al ${ }^{42}$ & 2002 & $C(R)$ & 112 & 112 & 112 & 0 & NR & \multicolumn{2}{|c|}{ F 29.2, M 43.1 NR } \\
\hline Mangano and Bartolucci ${ }^{41}$ & 2001 & $\mathrm{C}(\mathrm{R})$ & 69 & 69 & 69 & 0 & $16-61$ & 42 & Private \\
\hline Muftu and Chapman ${ }^{46}$ & 1998 & $\mathrm{C}(\mathrm{P})$ & 168 & NR & NR & NR & NR & NR & Hospital \\
\hline
\end{tabular}

*Study design shown in parentheses. $N R=$ not reported, $\mathrm{R}=$ retrospective, $\mathrm{P}=$ prospective.

All selected studies ${ }^{25-51}$ were published in the last 12 years. The publication date of the external-connection implant systems ranged from 1996 to 2004 with half of the studies published after 2000. The publication date of the internal-connection implant systems ranged from 1998 to 2006, with the majority of the studies published after 2000 . No study directly compared the incidence of screw loosening between internal- and external-connection implant systems. Most of the studies were classified as category $C$ according to the strength of the evidence, and most were implemented in a university setting.

The studies included a total of 2,038 patients with an age range of 13 to 90 years. The demographics of the included studies are depicted in Tables 3 and 4. The studies reported on various commercially avail- able implant systems. Most of the external-connection implant systems included in the final studies were either 3i (Biomet 3i, Palm Beach Gardens, FL) or Nobel Biocare (Nobel Biocare, Göteborg, Sweden), which essentially have similar geometry for their respective regular platforms. The exception was 1 study that utilized Threadlock/Spline (Sulzer Calcitek, Carlsbad, CA) implants. The internal-connection systems were Straumann (Straumann, Basel, Switzerland), Astra (Astra Tech, Mölndal, Sweden), Frialit (Friatec, Mannheim, Germany), Mac System (Cabon, Milan, Italy), Bicon (Bicon, Boston, MA), and Ankylos (Degussa Hulls, Hanau, Germany). Due to the possible effect of the variability of internal-connection geometry on the stability of the implant-abutment interface, the internal connection group of studies was 


\section{Table 5 Information on SIRs in Included Studies with External Connection}

\begin{tabular}{|c|c|c|c|c|c|c|c|c|}
\hline Study & Year & $\begin{array}{l}\text { Implant } \\
\text { system }\end{array}$ & $\begin{array}{c}\text { Planned } \\
\text { total } \\
\text { no. of } \\
\text { implants }\end{array}$ & $\begin{array}{c}\text { Planned } \\
\text { no. of } \\
\text { SIR* }\end{array}$ & $\begin{array}{c}\text { Actual } \\
\text { no. of } \\
\text { SIR }\end{array}$ & $\begin{array}{c}\text { Drop out } \\
\%\end{array}$ & $\begin{array}{l}\text { Follow-up } \\
\text { range (y) }\end{array}$ & $\begin{array}{c}\text { Mean } \\
\text { follow-up } \\
\text { (y) }\end{array}$ \\
\hline Andersson et $\mathrm{al}^{28}$ & 1998 & Nobel Biocare & 65 & 65 & 55 & 15 & $\mathrm{~N} / \mathrm{A}$ & 5 \\
\hline Andersson et $\mathrm{al}^{34}$ & 2001 & Nobel Biocare & 20 & 20 & 20 & 0 & $\mathrm{~N} / \mathrm{A}$ & 3 \\
\hline Balshi et $\mathrm{al}^{33}$ & 1996 & Nobel Biocare & 72 & 8 & 8 & 0 & $\mathrm{~N} / \mathrm{A}$ & 3 \\
\hline Bambini et al ${ }^{26}$ & 2001 & Threadlock/Spline & 96 & 32 & 32 & 0 & $\mathrm{~N} / \mathrm{A}$ & 3 \\
\hline Cho et $\mathrm{al}^{27}$ & 2004 & $3 \mathrm{i}$ & 213 & 39 & 39 & 0 & $3-5$ & 4 \\
\hline Gibbard and Zarb ${ }^{32}$ & 2002 & Nobel Biocare & 49 & 49 & 30 & 38.8 & $5-13$ & 5 \\
\hline Glauser et $\mathrm{al}^{36}$ & 2004 & Nobel Biocare & 53 & 53 & 36 & 32 & $4-4.5$ & 4.1 \\
\hline Parein et $\mathrm{al}^{29}$ & 1997 & Nobel Biocare & 392 & 35 & 35 & 0 & NR & 4.2 \\
\hline Scheller et $\mathrm{al}^{31}$ & 1998 & Nobel Biocare & 99 & 99 & 65 & 34.3 & $\mathrm{~N} / \mathrm{A}$ & 5 \\
\hline Scholander et $\mathrm{al}^{30}$ & 1999 & Nobel Biocare & 259 & 208 & 208 & 0 & $2.5-9$ & 4.4 \\
\hline Vigolo et al ${ }^{35}$ & 2004 & $3 i$ & 24 & 24 & 24 & 0 & $\mathrm{~N} / \mathrm{A}$ & 4 \\
\hline
\end{tabular}

* Refers to SIR with antirotational features.

$\mathrm{N} / \mathrm{A}=$ not applicable; $\mathrm{NR}=$ not reported.

\section{Table 6 Information on SIRs in Included Studies with Internal Connection}

\begin{tabular}{|c|c|c|c|c|c|c|c|c|}
\hline Study & Year & $\begin{array}{l}\text { Implant } \\
\text { system }\end{array}$ & $\begin{array}{l}\text { Planned } \\
\text { total } \\
\text { no. of } \\
\text { implants }\end{array}$ & $\begin{array}{l}\text { Planned } \\
\text { no. of } \\
\text { SIR }\end{array}$ & $\begin{array}{l}\text { Actual } \\
\text { no. of } \\
\text { SIR }\end{array}$ & $\begin{array}{c}\text { Drop out } \\
\% \\
\text { of SIR }\end{array}$ & $\begin{array}{l}\text { Follow-up } \\
\text { range (y) }\end{array}$ & $\begin{array}{c}\text { Mean } \\
\text { follow-up } \\
\text { (y) }\end{array}$ \\
\hline Behneke et al ${ }^{39}$ & 2000 & ITI & 114 & 19 & 19 & 0 & $5-8.3$ & 5.4 \\
\hline Brägger et al ${ }^{44}$ & 2005 & ITI & 179 & 69 & 65 & 6 & 8-12 & 10 \\
\hline Duncan et al ${ }^{43}$ & 2003 & ITI & 186 & 34 & 34 & 0 & $\mathrm{~N} / \mathrm{A}$ & 3 \\
\hline Mericske-Stern et al ${ }^{45}$ & 2001 & ITI & 109 & 109 & 106 & 2.8 & $1-9$ & 4.2 \\
\hline Nedir et al ${ }^{51}$ & 2006 & ITI & 528 & 171 & 155 & 9.3 & $3-8$ & 3 \\
\hline Levine et $\mathrm{al}^{37}$ & 1999 & ITI & 174 & 174 & 157 & 10 & $2+$ & 3.3 \\
\hline Wennström et al ${ }^{50}$ & 2005 & Astra & 45 & 45 & 40 & 10.1 & $\mathrm{~N} / \mathrm{A}$ & 5 \\
\hline Gotfredsen et al ${ }^{49}$ & 2004 & Astra & 20 & 20 & 20 & 0 & $\mathrm{~N} / \mathrm{A}$ & 5 \\
\hline Norton 48 & 2006 & Astra & 181 & 181 & 180 & 0.6 & $1.8-7.6$ & 3 \\
\hline Norton 40 & 2001 & Astra & 27 & 27 & 14 & 48 & $4-7$ & 5.25 \\
\hline Palmer et al $\left.\right|^{38}$ & 2000 & Astra & 15 & 15 & 14 & 6.7 & $\mathrm{~N} / \mathrm{A}$ & 5 \\
\hline Romanos and Nentwig ${ }^{47}$ & 2000 & Ankylos & 58 & 58 & 7 & 88 & $>5 y$ & 5 \\
\hline Krennmair et al ${ }^{42}$ & 2002 & Frialit & 146 & 146 & 144 & 1.4 & $0.25-7$ & 3 \\
\hline Mangano and Bartolucci ${ }^{41}$ & 2001 & Mac System & 80 & 80 & 78 & 2.5 & NR & 3.5 \\
\hline Muftu and Chapman ${ }^{46}$ & 1998 & Bicon & 432 & 82 & 80 & 2.4 & $\mathrm{~N} / \mathrm{A}$ & 4 \\
\hline
\end{tabular}

$\mathrm{N} / \mathrm{A}=$ not applicable, $\mathrm{NR}=$ not reported .

further categorized into 3 categories: "Straumann," "Astra," and "Other." The information on implants and SIR is depicted in Tables 5 and 6.

The external-connection group comprised 12 studies following 586 SIR for a mean follow-up time that ranged from 3 to 5 years (Table 7). The estimated percentage of complication-free SIR after 3 years was 97.3\% (95\% Cl: 95.6-98.3).

The internal-connection group comprised 15 studies following 1,113 SIR for a mean follow-up time that ranged from 3 to 10 years (Table 8). The estimated percentage of complication-free SIR after 3 years was 97.6\% (95\% Cl: 96.5-98.3). The complication-free percentage of SIR for the 3 groups was as follows: Straumann 98.2\% (95\% Cl: 96.8-99.0), Astra 97.0\% (95\% Cl: 94.4-98.4), and Other 97.1\% (95\% Cl: 94.7-98.5).
The design of the study (prospective versus retrospective) did not have any effect on the outcome. The estimated percentage of complication-free SIR after 3 years was as follows: external connection/ prospective 97.2\% (95\% Cl: 94.9-98.5), external connection/retrospective $97.1 \%$ (95\% Cl: 93.6-98.7), internal connection/prospective $97.6 \%(95 \% \mathrm{Cl}$ : 95.9-98.6), and internal connection/retrospective 97.6\% (95\% Cl: 95.8-98.6).

\section{DISCUSSION}

Systematic reviews differ from other types of reviews in that they adhere to a strict scientific design to make them more comprehensive to minimize the 


\section{Table 7 Abutment Screw Loosening Rates of External-Connection Implants}

\begin{tabular}{|c|c|c|c|c|c|c|c|}
\hline Study & Year & $\begin{array}{c}\text { Total } \\
\text { no. of } \\
\text { implants }\end{array}$ & $\begin{array}{c}\text { Mean } \\
\text { follow-up } \\
\text { time (y) }\end{array}$ & $\begin{array}{l}\text { No. of } \\
\text { failure } \\
\text { (loosen) }\end{array}$ & $\begin{array}{c}\text { Estimated } \\
\text { minimum } \\
\text { time exposure } \\
\text { (y) }\end{array}$ & $\begin{array}{l}\text { Estimated } \\
\text { failure rate } \\
\text { (per } 100 \\
\text { implant years) }\end{array}$ & $\begin{array}{l}\text { Estimated } \\
\text { complication-free: } \\
\% \text { after } 3 y\end{array}$ \\
\hline Andersson et $\mathrm{al}^{28}$ & 1998 & 55 & 5 & 0 & 275 & 0.00 & 100 \\
\hline Andersson et $\mathrm{al}^{34}$ & 2001 & 20 & 3 & 0 & 60 & 0.00 & 100 \\
\hline Balshi et $\mathrm{al}^{33}$ & 1996 & 8 & 3 & 0 & 24 & 0.00 & 100 \\
\hline Bambini² $^{26}$ & 2001 & 32 & 3 & 3 & 96 & 3.13 & 91.1 \\
\hline $\mathrm{Cho}^{27}$ & 2004 & 39 & 4 & 0 & 156 & 0.00 & 100 \\
\hline Gibbard and Zarb 32 & 2002 & 30 & 5 & 0 & 150 & 0.00 & 100 \\
\hline Glauser et al ${ }^{36}$ & 2004 & 36 & 4.1 & 2 & 148 & 1.36 & 96.0 \\
\hline Parein et $\mathrm{al}^{29}$ & 1997 & 35 & 4.2 & 1 & 147 & 0.68 & 98.0 \\
\hline Scheller et $a^{31}$ & 1998 & 65 & 5 & 4 & 325 & 1.23 & 96.4 \\
\hline Scholander et $\mathrm{al}^{30}$ & 1999 & 208 & 4.4 & 2 & 915 & 0.22 & 99.3 \\
\hline Vigolo et $\mathrm{al}^{35}$ & 2004 & 24 & 4 & 0 & 96 & 0.00 & 100 \\
\hline Wannfors and Smedberg 25 & 1999 & 34 & 3 & 1 & 102 & 0.98 & 97.1 \\
\hline Total & & 586 & & 13 & 2,494 & & \\
\hline Summary estimate & & & & & & $0.92(0.57-1.50)$ & $97.3(95.6-98.3)$ \\
\hline
\end{tabular}

\section{Table 8 Abutment Screw Loosening Rates of Internal-Connection Implants (per Implant Type and Total)}

\begin{tabular}{|c|c|c|c|c|c|c|c|c|}
\hline Study & Year & $\begin{array}{l}\text { Type of } \\
\text { implant }\end{array}$ & $\begin{array}{c}\text { Total } \\
\text { no. of } \\
\text { implants }\end{array}$ & $\begin{array}{c}\text { Mean } \\
\text { follow-up } \\
\text { time (y) }\end{array}$ & $\begin{array}{l}\text { No. of } \\
\text { failure } \\
\text { (loosen) }\end{array}$ & $\begin{array}{c}\text { Estimated } \\
\text { minimum } \\
\text { time } \\
\text { exposure (y }\end{array}$ & $\begin{array}{l}\text { Estimated } \\
\text { failure rate } \\
\text { (per } 100 \\
\text { y) implant years) }\end{array}$ & $\begin{array}{l}\text { Estimated } \\
\text { complication-free: } \\
\% \text { after } 3 \mathrm{y}\end{array}$ \\
\hline Behneke et al ${ }^{39}$ & 2000 & Straumann & 19 & 5.4 & 1 & 103 & 0.97 & 97.1 \\
\hline Brägger et al ${ }^{44}$ & 2005 & Straumann & 65 & 10 & 2 & 650 & 0.31 & 99.1 \\
\hline Duncan et al ${ }^{43}$ & 2003 & Straumann & 34 & 3 & 0 & 102 & 0.00 & 100 \\
\hline Mericske-Stern et al ${ }^{45}$ & 2001 & Straumann & 106 & 4.2 & 0 & 445 & 0.00 & 100 \\
\hline Nedir et al ${ }^{51}$ & 2006 & Straumann & 155 & 3 & 2 & 465 & 0.43 & 98.7 \\
\hline Levine et $\mathrm{al}^{37}$ & 1999 & Straumann & 157 & 3.3 & 5 & 518 & 0.97 & 97.1 \\
\hline Total & & & 536 & & 10 & 2,283 & & \\
\hline \multicolumn{3}{|l|}{ Summary estimate $(95 \% \mathrm{Cl})$} & & & & & $0.59(0.33-1.07)$ & $98.2(96.8-99.0)$ \\
\hline Wennström et $\mathrm{al}^{50}$ & 2005 & Astra & 40 & 5 & 2 & 200 & 1.00 & 97.0 \\
\hline Gotfredsen 49 & 2004 & Astra & 20 & 5 & 2 & 100 & 2.00 & 94.2 \\
\hline Norton 48 & 2006 & Astra & 180 & 3 & 4 & 540 & 0.74 & 97.8 \\
\hline Norton $^{40}$ & 2001 & Astra & 14 & 5.25 & 1 & 74 & 1.36 & 96.0 \\
\hline Palmer et $\mathrm{al}^{38}$ & 2000 & Astra & 14 & 5 & 0 & 70 & 0.00 & 100 \\
\hline Total & & & 268 & & 9 & 984 & & \\
\hline \multicolumn{3}{|l|}{ Summary estimate $(95 \% \mathrm{Cl})$} & & & & & $1.03(0.54-1.93)$ & $97.0(94.4-98.4)$ \\
\hline Romanos and Nentwig ${ }^{47}$ & 2000 & Other & 7 & 5 & 0 & 35 & 0.00 & 100 \\
\hline Krennmair et al ${ }^{42}$ & 2002 & Other & 144 & 3.0 & 5 & 432 & 1.16 & 96.6 \\
\hline Mangano and Bartolucci ${ }^{41}$ & 2001 & Other & 78 & 3.5 & 1 & 273 & 0.37 & 98.9 \\
\hline Muftu and Chapman ${ }^{46}$ & 1998 & Other & 80 & 4 & 3 & 320 & 0.94 & 97.2 \\
\hline Total & & & 309 & & 9 & 1,060 & & \\
\hline \multicolumn{3}{|l|}{ Summary estimate (95\% Cl) } & & & & & $0.97(0.51-1.82)$ & $97.1(94.7-98.5)$ \\
\hline Total & & & 1,113 & & 28 & 4,327 & & \\
\hline \multicolumn{3}{|l|}{ Summary estimate $(95 \% \mathrm{Cl})$} & & & & & $0.83(0.58-1.18)$ & $97.6(96.5-98.3)$ \\
\hline
\end{tabular}


chance of bias and to ensure their reliability. Rather than reflecting the views of the authors or being based on only a (possibly biased) selection of the published literature, they contain a comprehensive summary of the available evidence with strict inclusion and exclusion criteria. Methodologies for undertaking systematic reviews have been described. 87,88 The gold standard for systematic reviews is to study randomized clinical trials (RCT), which are the studies with the most robust design. Most of the studies included in this review were retrospective. They were classified in category $\mathrm{C}$ according to the strength of evidence and clearly indicate a lower quality of data compared with prospective studies. ${ }^{24}$ This clearly points out the need for clinical studies with better designs. No RCTs existed which directly compared the incidence of abutment screw loosening between external and internal connection implant systems. The effect of study design (prospective versus retrospective) was not significant; therefore, the results could be pooled together.

Two reviewers were used to ensure that tasks such as selection of studies for inclusion and data extraction could be performed independently, increasing the chance that errors were detected. The interexaminer agreement ranged from good to perfect agreement. Database search was also augmented by hand searching to minimize selection bias. ${ }^{89}$

The exclusion of papers in languages other than English may have led to the omission of some papers. This is problematic for 2 reasons: (1) the precision of summary estimates could be reduced if a substantial number of additional studies published in other languages existed; (2) bias may have been introduced if the results of studies published in English differed systematically from those published in other languages. However, a recent empirical study found little effect of the inclusion/exclusion of trials published in language other than English on combined effect estimates in meta-analyses of RCTs. ${ }^{90}$ Moreover, it is difficult to have access to non-English journals all over the world, and it is hard to establish the features of the peer-review processes of these journals. When these non-English papers are selected, based on their abstracts, the contents must be translated. This includes the risk of interpretation problems. ${ }^{91}$

The majority of the studies included in this review were conducted in a university setting. The results may therefore not be applicable to all practice settings. The papers originating from private practice settings showed a tendency for a slightly higher incidence of abutment screw loosening, especially regarding internal-connection implant systems.

The follow-up time chosen was set at a minimum of 3 years which could be considered small. It was the authors' intention to try to include as many clinical studies as possible in order to reach a stronger conclusion. Had the cutoff point for mean follow-up time been set at 5 years, 17 more studies would have been excluded. Furthermore, it has been shown that most of mechanical problems take place in the first years after abutment connection. ${ }^{14-17}$ The mean follow-up time for the included studies ranged between from 3 to 10 years. However the results do not provide safe conclusions regarding the long-term stability of various implant-abutment connections.

The results of this review showed that abutment screw loosening is a rare event in SIR regardless of the implant-abutment connection geometry, provided that proper antirotational features and torque are employed. More than $97 \%$ of SIR studied maintained a stable implant-abutment connection after 3 years of service. This is in agreement with results from in vitro studies, ${ }^{18-21}$ which have demonstrated stable abutment screw joints for internal-connection implants as well as for external-connection implants with improved screw materials and preload. This study did not look into other types of mechanical complications, such as screw fracture, where implantabutment connection geometry might play a role. The results of this systematic review are in agreement with the results of a previous systematic review ${ }^{92}$ that examined the incidence of biological and technical complications in implant therapy reported in prospective longitudinal studies of at least 5 years. That study found a very low incidence of complications affecting implant-connection components after 5 years of clinical service. Another systematic review ${ }^{91}$ of single implants stated that maintenance treatments were quite common with approximately 1 out of 5 single-tooth implants in need of maintenance, varying from abutment screw retightening to crown remake. The study did not look specifically at the incidence of abutment screw loosening.

No attempt was made to distinguish between anterior and posterior SIR, even though one could assume that the vector of force is different. The reasons were that most of the studies did not specify the number of posterior versus anterior SIR and that the incidence of abutment screw loosening reported was extremely low. The same holds true for the possible effect of restorative implant platform diameter and method of crown retention. In the majority of included studies, implants with a regular-diameter restorative platform and cement-retained restorations were used. The method of reporting did not permit the statistical analysis of the possible effect of the aforementioned clinical factors on the incidence of abutment screw loosening. 


\section{CONCLUSION}

The results show that abutment screw loosening is a rare event in SIR regardless of the geometry of implant-abutment connection, provided that proper antirotational features and torque are employed.

\section{REFERENCES}

1. Patterson EA, Johns RB. Theoretical analysis of the fatigue life of fixture screws in osseointegrated dental implants. Int J Oral Maxillofac Implants 1992;7:26-34.

2. Binon PP, McHugh JM. The effect of eliminating implant/abutment rotational misfit on screw joint stability. Int J Prosthodont 1996;9:511-519.

3. Jorneus L, Jemt T, Carlsson L. Loads and designs of screw joints for single crowns supported by osseointegrated implants. Int J Oral Maxillofac Implants 1992;7:353-359.

4. Norton MR. Assessment of cold welding of the internal conical interface of two commercially available implant systems.J Prosthet Dent 1999;81:159-166.

5. Schwarz MS. Mechanical complications of dental implants. Clin Oral Implants Res 2000;11:156-158.

6. Nikopoulou F. Saliva and dental implants. Implant Dent 2006; 15:372-374.

7. Khraisat A, Abu-Hammad O, Al-Kayed AM, Dar-odeh N. Stability of the implant/abutment joint in a single-tooth externalhexagon implant system: Clinical and mechanical review. Clin Implant Dent Relat Res 2004;6:222-229.

8. McGlumphy EA. Implant screw mechanics. Dent Clin North Am 1998;42:71-89.

9. Merz BR, Hunenbart S, Belser UC. Mechanics of the implantabutment connection: An 8-degree taper compared to a buttjoint connection. Int J Oral Maxillofac Implants 2000;15: 519-526.

10. Balfour A, O'Brien GR. Comparative study of antirotational single tooth abutments. J Prosthet Dent 1995;73:36-43.

11. Norton MR. An in-vitro evaluation of the strength of an internal conical interface compared to a butt joint interface in implant design. Clin Oral Implant Res 1997;8:290-298.

12. Weiss El, Kozak D, Gross MD. Effect of repeated closures on opening torque values in seven abutment-implant systems.J Prosthet Dent 2000;84:194-199.

13. Piermatti J, Yousef $H$, Luke A, Mahevich R, Weiner $S$. An in vitro analysis of implant screw torque loss with external hex and internal connection implant systems. Implant Dent 2006;15: 427-432.

14. Jemt T, Pettersson P. A 3-year follow-up study on single implant treatment. J Dent 1993;21:203-208.

15. Ekfeldt A, Carlsson GE, Borjesson G. Clinical evaluation of single-tooth restorations supported by osseointegrated implants: A retrospective study. Int J Oral Maxillofac Implants 1994;9:179-183.

16. Engquist $B$, Nilson $H$, Astrand P. Single-tooth replacement by osseointegrated Branemark implants. A retrospective study of 82 implants. Clin Oral Implants Res 1995;6:238-245.

17. Henry PJ, Laney WR, Jemt T, et al. Osseointegrated implants for single-tooth replacement: A prospective 5-year multicenter study. Int J Oral Maxillofac Implants 1996;11:450-455.

18. Martin WC, Woody RD, Miller BH, Miller AW. Implant abutment screw rotations and preloads for four different screw materials and surfaces. J Prosthet Dent 2001;86:24-32.
19. Drago CJ. A Clinical study of the efficacy of gold-tite square abutment screws in cement-retained implant restorations. Int J Oral Maxillofac Implants 2003;18:273-278.

20. Tan KB, Nicholls Jl. Implant-abutment screw joint preload of 7 hex-top abutment systems. Int J Oral Maxillofac Implants 2001;16:367-377.

21. Siamos G, Winkler S, Boberick KG. Relationship between implant preload and screw loosening on implant-supported prostheses. J Oral Implantol 2002;28:67-73.

22. Millennium Research Group. US markets for dental implants: Executive summary. Implant Dent 2003;12:108-111.

23. Millennium Research Group. European markets for dental implants and final abutments 2004: Executive summary. Implant Dent 2004;13:193-196.

24. Jokstad A, Brägger U, Brunski JB, Carr A, Naert I, Wennerberg A. Quality of dental implants. Int Dent J 2003;53:409-443.

25. Wannfors K, Smedberg J-I. A prospective clinical evaluation of different single-tooth restorations designs on osseointegrated implants. A 3-year follow-up of Brånemark Implants. Clin Oral Implants Res 1999;10:453-458.

26. Bambini F, Lo Muzio L, Procaccini M. Retrospective analysis of the influence of abutment structure design on the success of implant unit. A 3-year controlled follow-up study. Clin Oral Implants Res 2001;12:319-324.

27. Cho S-C, Paula N, Elian N, Tarnow D. Screw loosening for standard and wide diameter implants in partially edentulous cases: 3- to 7-year longitudinal data. Implant Dent 2004;13: 245-250.

28. Andersson B, Ödman P, Lindvall AM, Brånemark PI. Cemented single crowns on osseointegrated implants after 5 years: Results from a prospective study on CeraOne. Int J Prosthodont 1998;11:212-218.

29. Parein AM, Eckert SE, Wollan PC, Keller EE. Implant reconstruction in the posterior mandible: A long-term prospective study. J Prosthet Dent 1997;78:34-42.

30. Scholander S. A Retrospective evaluation of 259 single-tooth replacements by the use of Brånemark implants. Int J Prosthodont 1999;12:483-491.

31. Scheller H, Urgell PJ, Kultje C, et al. A 5-year multicenter retrospective study on implant supported single crown restorations. Int J Oral Maxillofac Implants 1998;13:212-218.

32. Gibbard LL, Zarb GA. A 5-year prospective study of implantsupported single-tooth replacements. J Can Dent Assoc 2002; 68:110-116.

33. Balshi TJ, Hernandez RE, Pryszlak MC, Rangert B. A comparative study of one implant versus two replacing a single molar. Int J Oral Maxillofac Implants 1996;11:372-378.

34. Andersson B, Taylor A, Lang BR, et al. Alumina ceramic implant abutments used for single-tooth replacement: A prospective 1- to 3- year multicenter study. Int J Prosthodont 2001;14: 432-438.

35. Vigolo P, Givani A, Majzoub Z, Cordioli G. Cemented versus screw-retained implant-supported single-tooth crowns: A 4year prospective clinical study. Int J Oral Maxillofac Implants 2004;19:260-265.

36. Glauser R, Sailer I, Wohlwend A, Studer S, Schibli M, Scharer P. Experimental zirconia abutments for implant-supported single-tooth restorations in esthetically demanding regions: 4year results of a prospective clinical study. Int J Prosthodont 2004;17:285-290.

37. Levine LR, Clem SD III, Wilson GT, Higginboth F, Solnit G. Multicenter retrospective analysis of the ITI implant system used for single-tooth replacements: Results of loading for 2 or more years. Int J Oral Maxillofac Implants 1999;14:516-520. 
38. Palmer RM, Palmer PJ, Smith BJ. A 5-year prospective study of Astra single-tooth implants. Clin Oral Implants Res 2000;11: 179-182.

39. Behneke A, Behneke N, d'Hoedt B. The longitudinal clinical effectiveness of ITI solid screw implants in partially edentulous patients: A 5-year follow-up report. Int J Oral Maxillofac Implants 2000;15:633-645.

40. Norton M. Biologic and mechanical stability of single-tooth implants: 4- to 7-year follow-up. Clin Implant Dent Relat Res 2001;3:214-219.

41. Mangano C, Bartolucci GE. Single tooth replacement by morse taper connection implants: A retrospective study of 80 implants. Int J Oral Maxillofac Implants 2001;16:675-680.

42. Krennmair G, Schmidinger S, Waldenberger O. Single tooth replacement with the Frialit -2 system: $A$ retrospective clinical analysis of 146 implants. Int J Oral Maxillofac Implants 2002; 17:78-85.

43. Duncan PJ, Nazarova E, Vogiatzi T, Taylor DT. Prosthodontic complications in a prospective clinical trial of single-stage implants at 36 months. Int J Oral Maxillofac Implants 2003; 18:561-565.

44. Brägger U, Karoussis I, Persson R, Pjetursson B, Salvi G, Lang NP. Technical and biological complications/ failures with single crowns and fixed partial dentures on implants: A 10-year prospective cohort study. Clin Oral Implants Res 2005;16: 326-334.

45. Mericske-Stern R, Crutter L, Rosch R, Mericske E. Clinical evaluation and prosthetic complications of single tooth replacements by non-submerged implants. Clin Oral Implants Res 2001;12:309-318.

46. Muftu A, Chapman RJ. Replacing posterior teeth with freestanding implants: Four-year prosthodontic results of a prospective study. J Am Dent Assoc 1998;129:1097-1102.

47. Romanos EG, Nentwig HG. Single molar replacement with a progressive thread design implant system: A retrospective clinical report. Int J Oral Maxillofac Implants 2000;15:831-836.

48. Norton MR. Multiple single-tooth implant restorations in the posterior jaws: Maintenance of marginal bone levels with reference to the implant-abutment microgap. Int J Oral Maxillofac Implants 2006;21:777-784.

49. Gotfredsen K. A 5-year prospective study of single-tooth replacements supported by the Astra Tech implant: A pilot study. Clin Implant Dent Relat Res 2004;6:1-9.

50. Wennström JL, Ekestubbe A, Grondahl K, Karlsson S, Lindhe J. Implant supported single-tooth restorations: A 5-year prospective study. J Clin Periodontol 2005;32:567-574.

51. Nedir R, Bischof M, Szmukler-Moncler S, Belser CU, Samson J. Prosthetic complications with dental implants: From an upto-8-year experience in private practice. Int J Oral Maxillofac Implants 2006;21:919-928.

52. Levine LA, Clem DS III, Wilson TG, Higginbottom F, Saunders SL. A Multicenter retrospective analysis of the ITI Implant system used for single tooth replacements: Preliminary results at 6 or more months of loading. Int J Oral Maxillofac Implants 1997;12:237-242.

53. McMillan AS, Allen PF, Bin Ismail I. A retrospective multicenter evaluation of single tooth implant experience at three centers in the United Kingdom. J Prosthet Dent 1998;79:410-414.

54. Dhanrajani PJ, Al Rafee MA. Single-tooth implant restorations: A retrospective study. Implant Dent 2005;14:125-130.

55. Ericsson I, Nilson H, Lindh T, Nilner K, Randow K. Immediate functional loading of Brånemark single tooth implants. An 18 months' clinical pilot follow-up study. Clin Oral Implants Res 2000;11:26-33.
56. Lindquist LW, Carlsson GE, Jemt T. A prospective 15-year follow-up study of mandibular prostheses supported by osseointegrated implants. Clin Oral Implants Res 1996;7: 329-336.

57. Priest G. Single-tooth implants and their role in preserving remaining teeth: A 10-year survival study. Int J Oral Maxillofac Implants 1999;14:181-188.

58. Levine LR, Clem D, Beagle J, et al. Multicenter retrospective analysis of the solid screw ITI implant for posterior single tooth replacements. Int J Oral Maxillofac Implants 2002;17: 550-556.

59. Schropp L, Kostopoulos L, Wenzel A, Isidor F. Clinical and radiographic performance of delayed-immediate single-tooth implant placement associated with peri-implant bone defects. A 2-year prospective, controlled, randomized follow up report. J Clin Periodontol 2005;32:480-487.

60. Andersson L, Emami-Kristiansen Z, Högström J. Single-tooth implant treatment in the anterior region of the maxilla for treatment of tooth loss after trauma: A retrospective clinical and interview study. Dental Traumatology 2003;19:126-131.

61. Vermylen K, Collaert B, Linde U, Bjorn A-L, De Bruyn H. Patient satisfaction and quality of single-tooth restorations. Clin. Oral Implants Res 2003;14:119-124.

62. Karlsson U, Gotfredsen J, Olsson C. Single-tooth replacement by osseointegrated Astra Tech dental implants: A 2-year report. Int J Prosthodont 1997;10:318-324.

63. Jemt $T$, Bergendal B, Arvidsson $\mathrm{K}$, et al. Laser-welded titanium frameworks supported by implants in the edentulous maxilla: A 2-year prospective multicenter study. Int J Prosthodont 1998;11:551-557.

64. Wie H. Registration of localization, occlusion and occluding materials for failing screw joints in the Brånemark implant system. Clin Oral Implants Res 1995;6:47-53.

65. Lekholm U, van Steenberghe D, Herrmann I, et al. Osseointegrated implants in the treatment of partially edentulous jaws: A prospective 5-year multicenter study. Int J Oral Maxillofac Implants 1994;9:627-635.

66. Lekholm U, Gunne J, Henry P, et al. Survival of the Brånemark Implant in partially edentulous jaws: A 10-year prospective multicenter study. Int J Oral Maxillofac Implants 1999;14: 639-645.

67. Jemt $T$, Henry $P$, Linden B, Naert I, Weber H, Bergström C. A comparison of laser welded titanium and conventional cast frameworks supported by implants in the partially edentulous jaw: A 3-year prospective multicenter study. Int J Prosthodont 2000;13:282-288

68. Simon LR. Single implant-supported molar and premolar crowns: A 10-year retrospective clinical report. J Prosthet Dent 2003;90:517-521.

69. Kourtis GS, Sotiriadou S, Voliotis S, Challas A. Private practice results of dental implants. Part I: Survival and evaluation of risk factors. Part II: Surgical and prosthetic complications. Implant Dent 2004;4:373-382.

70. Haas R, Mensdorff-Pouilly N, Mailath G, Watzek G. Brånemark single tooth implants: A preliminary report of 76 implants. J Prosthet Dent 1995;73:274-279.

71. Polizzi G, Fabbro S, Furri M, Herrmann I, Squarzoni S. Clinical application of narrow Brånemark system implants for singletooth restorations. Int J Oral Maxillofac Implants 1999;14:496-503.

72. De Boever AL, Keersmaekers K, Vanmaele G, Kerschbaum K, Theuniers G, De Boever JA. Prosthetic complications in fixed endosseous implant-borne reconstructions after an observations period of at least 40 months. J Oral Rehabil 2006;33:833-839. 
73. Scurria S M, Morgan ZV, Guckes DA, Li S, Koch G. Prognostic variables associated with implant failure: $A$ retrospective effectiveness study. Int J Oral Maxillofac Implants 1998;13: 400-406.

74. Bher M, Lang R, Leibrock A, Rosentritt M, Handel G. Complication rate with prosthodontic reconstructions on ITI and IMZ dental implants. Clin Oral Implants Res 1998;9:51-58.

75. Wee AG, McGlumphy EA. Prosthodontic complications of Spline dental implants. Implant Dent 2003;12:151-159.

76. Balshi TJ, Wolfinger GJ. Two-implant-supported single molar replacement: Interdental space requirements and comparison to alternative options. Int J Periodontics Restorative Dent 1997;17:426-435.

77. Fartash B, Arvidson K. Long-term evaluation of single crystal sapphire implants as abutments in fixed prosthodontics. Clin Oral Implants Res 1997;8:58-67.

78. Moberg L-E, Kondell P-A, Kullman L, Heimdalh A, Gynther WG. Evaluation of single tooth restorations on ITI dental implants. A prospective study of 29 patients. Clin Oral Implants Res 1999;10:45-53.

79. Weigl P. New prosthetic restorative features of the Ankylos implant system. J Oral Implantol 2004;30:178-188.

80. Döring K, Eisenmann E, Stiller M. Functional and esthetic considerations for single-tooth Ankylos implant crowns: 8 years of clinical performance. J Oral Implantol 2004;30:198-209.

81. Cooper L, Felton AD, Kugelberg FC, et al. A multicenter 12month evaluation of single-tooth implants restored 3 weeks after 1-stage surgery. Int J Oral Maxillofac Implants 2001;16: 182-192.

82. Norton MR. A short-term clinical evaluation of immediately restored maxillary TiO-blast single-tooth implants. Int J Oral Maxillofac Implants 2004;19:274-281.
83. Wennström JL, Ekestubbe A, Grondahl K, Karlsson S, Lindhe J. Oral rehabilitation with implant supported fixed partial dentures in periodontitis susceptible subjects. A 5-year prospective study. J Clin Periodontol 2004;31:713-724.

84. Schwartz-Arad D, Samet N, Samet N. Single tooth replacement of missing molars: A retrospective study of 78 implants. J Periodontol 1999;70:449-454.

85. Wyatt CC, Zarb GA. Treatment outcomes of patients with implant-supported fixed partial prostheses. Int J Oral Maxillofac Implants 1998;13:204-211.

86. Carlson B, Carlsson GE. Prosthodontic complications in osseointegrated dental implant treatment. Int J Oral Maxillofac Implants 1994;9:90-94.

87. Higgins JPT, Green S (eds). Cochrane Handbook for Systematic Reviews of Interventions 4.2.6 [updated September 2006]. In: The Cochrane Library, Issue 4, 2006. Chichester, UK: John Wiley \& Sons, 2006.

88. Needleman IG. A guide to systematic reviews. J Clin Periodontol 2002;29(suppl 3):6-9.

89. Hopewell S, Clarke M, Lefebvre C, Scherer R. Hand searching versus electronic searching to identify reports of randomized trials. Cochrane Database of Systematic Reviews 2007, Issue 2. Art. No.: MR000001.pub2

90. Egger M, Jüni P, Bartlett C, Holenstein F, Sterne J. How important are comprehensive literature searches and the assessment of trial quality in systematic reviews? Empirical study. Health Technol Assess 2003;7:1-76.

91. Creugers NHJ, Kreulen CM, Snoek PA, de Kanter RJAM. A systematic review of single-tooth restorations supported by implants. J Dent 2000;28:209-217.

92. Berglundh T, Persson L, Klinge B. A systematic review of the incidence of biological and technical complications in implant dentistry reported in prospective longitudinal studies of at least 5 years. J Clin Periodontol 2002;29(suppl 3):197-212. 